\title{
Pengembangan Media Pembelajaran Matematika Interaktif Berbasis Android pada Materi Dimensi Tiga Kelas X SMA
}

\author{
Doni Dwiranata ${ }^{1}$, Dewi Pramita ${ }^{2}$, Syaharuddin ${ }^{3}$ \\ ${ }_{1,2,3}$ Pendidikan Matematika, Universitas Muhammadiyah Mataram \\ e-mail: ${ }^{1}$ dhony.dwyranata025@gmail.com, ${ }^{2}$ mitha_dhewi@yahoo.com, ${ }^{3}$ abialmusthafa@gmail.com
}

\begin{abstract}
This study aims to develop and produce android-based mathematics learning media on the subject of three dimensions of point, line, and field positions in space, for class X high school students and find out the validity, effectiveness, and practicality of interactive multimedia-based learning media. This type of research is a research development in the form of a three dimensional interactive learning media. Media development refers to the ADDIE development model which includes 5 stages, namely Analysis, Design, Development, Implementation, Evaluation. The subjects of this study were students of class X IPA and students of class X IPS SMA Negeri 1 Maronge. The instruments used in this study were questionnaire validation of material experts and media experts, student questionnaire responses, and student evaluation tests. The results of the development research are: (1) The results of the validation of the material and the media obtain an average score of 36 with the category "quite valid"; (2) The results of the effectiveness of the media in small group trials have achieved 100\% mastery learning in the "very effective" category; (3) The results of the practicality of the media in small group trials obtained an average score of 57 in the "very practical" category; (4) The results of the effectiveness of the media in large group trials gained mastery learning reaching $80 \%$ with the category of "effective"; and (5) The practicality of the media in the large group test obtained an average of 54,485 in the "practical" category.
\end{abstract}

Key words: Interactive Media based on Android, ADDIE development Model, Geometry, Adobe Flash.

\begin{abstract}
Abstrak
Penelitian ini bertujuan untuk mengembangkan dan menghasilkan media interaktif pembelajaran matematika berbasis android pada pokok bahasan dimensi tiga materi kedudukan titik, garis, dan bidang dalam ruang, untuk siswa SMA kelas X. Jenis penelitian ini adalah penelitian pengembangan media pembelajaran dengan model pengembangan ADDIE yang meliputi 5 tahap, yaitu Analysis, Design, Development, Implementation, Evaluation. Subjek penelitian ini adalah siswa kelas X IPA dan siswa kelas X IPS SMA Negeri 1 Maronge sebanyak (55) siswa. Instrumen yang digunakan dalam penelitian ini adalah angket validasi ahli materi dan ahli media, angket respon siswa, dan tes evaluasi siswa. Hasil penelitian diketahui bahwa: (1) Hasil validasi materi dan media memperoleh skor rata-rata 36 dengan kategori "cukup valid"; (2) Hasil keefektifan media pada uji coba kelompok kecil memperoleh ketuntasan belajar mencapai 100\% dengan kategori "sangat efektif"; (3) Hasil kepraktisan media pada uji coba kelompok kecil memperoleh skor rata-rata 57 dengan kategori "sangat praktis"; (4) Hasil keefektifan media pada uji coba kelompok besar memperoleh ketuntasan belajar mencapai 80\% dengan kategori "efektif"; dan (5) Hasil kepraktisan media pada uji kelompok besar memperoleh rata-rata 54,485 dengan kategori "praktis".
\end{abstract}

Kata Kunci: Media Interaktif Berbasis Android, Model Pengembangan ADDIE, Dimensi Tiga, Adobe Flash. 


\section{PENDAHULUAN}

Pendidikan merupakan sebagian usaha sadar dan terencana untuk mewujudkan suasana belajar dan proses pembelajaran yang dilakukan orangorang yang diserahi tanggung jawab yang mempengaruhi peserta didik agar mempunyai sifat dan tabiat sesuai dengan cita-cita pendidikan [1]. Pendidikan merupakan upaya manusia untuk memperluas pengetahuan dalam rangka membentuk nilai, sikap, dan prilaku sesuai dengan tujuan pendidikan, di mana pendidikan bagian yang sangat penting dalam kehidupan manusia, sebab dengan pendidikan inilah manusia dapat hidup sesuai dengan tujuan dan fungsinya sebagai manusia. Untuk itu perlu upaya yang sungguh-sungguh dari berbagai pihak, keterlibatan semua pihak dalam pendidikan akan sangat berpengaruh terhadap keberhasilan pendidikan.

Kegiatan pendidikan tidak dapat dipisahkan dari kehidupan seseorang sejak ia dilahirkan hingga ia meninggal dunia, karena pendidikan merupakan proses pembinaan dan pembelajaran yang akan berguna untuk mencerdaskan kehidupan bangsa. Dalam hal ini yaitu bagaimana cara mengorganisasikan pembelajaran, bagaimana cara menyampaikan isi pembelajaran, dan bagaimana menata interaksi antara sumber-sumber belajar yang ada agar dapat berfungsi secara optimal [2]. Oleh sebab itu pendidikan memiliki jangkauan dan kajian yang sangat penting, terutama kajian pendidikan yang menyangkut pembelajaran disekolah, salah satunya yakni pembelajaran metematika.

Matematika merupakan ilmu universal yang mendasari perkembangan ternologi modern, mempunyai peran penting dalam berbagai disiplin dan memajukan daya pikir manusia. Perkembangan pesat dibidang teknologi informasi dan komunikasi dewasa ini dilandasi oleh perkembangan matematika [3]. Untuk menguasai dan menciptakan teknologi dimasa depan diperlukan matematika yang kuat sejak dini [4].

Namun pada kenyataannya sampai saat ini, matematika oleh sebagian besar siswa masih dianggap sebagai ilmu yang kering, teoritis, penuh dengan lambang-lambang, rumus-rumus yang sulit [5], [6]. Siswa belum memahami peran penting dari matematika sehingga matematika dianggap sebagai pelajaran yang membosankan dan menakutkan. Akibatnya matematika tidak lagi menjadi disiplin ilmu yang objektif-sistematis, tapi justru menjadi bagian yang sangat subjektif dan kehilangan sifat netralnya yang membuat motivasi siswa dalam matematika sangat rendah dan secara otomatis sikap siswa terhadap pelajaran matematika menjadi negatif. Untuk itulah perlu diciptakan sebuah kondisi belajar yang menyenangkan bagi siswa, dengan kondisi yang menyenangkan tersebut siswa lebih termotivasi dalam belajar serta dapat memperbaiki sikapnya terhadap pelajaran matematika dan pada akhirnya hasil belajar siswa menjadi lebih baik [7].

Berdasarkan hasil wawancara dengan salah satu guru mata pelajaran matematika yang ada di SMA Negeri 1 Maronge mengatakan bahwa: "Di SMA Negeri 1 Maronge telah memiliki fasilitas komputer. Akan tetapi dalam proses pembelajaran berlangsung di kelas X IPA dan IPS, guru belum memaksimalkan penggunaan media yang berbasis komputer seperti powerpoint, menggunakan powerpoint itu pun juga sangat jarang. dalam kegiatan pembelajaran materi dimensi tiga masih menggunakan metode ceramah dan tanya jawab. Hasil nilai ulangan materi dimensi tiga masih ada siswa yang kurang dari nilai rata-rata ketuntasan minimum (KKM) yaitu 70, sehingga guru harus melakukan remedial. Kemudian bahan ajar yang selama ini digunakan adalah buku teks dengan menggunakan media papan tulis. Penggunaaan media papan tulis untuk pembelajaran materi dimensi tiga dirasakan kurang optimal, karena memakan banyak waktu, guru harus menggambar terlebih dahulu dipapan tulis untuk penyampaian materi, selain itu, apabila siswa belum mengerti tentang konsep yang diajarkan guru, maka gurupun harus menggambar ulang kembali untuk mengulangi penjelasannya."

Dari hasil observasi dan wawancara tersebut dapat disimpulkan bahwa dalam proses belajar mengajar di kelas X IPA dan IPS guru belum memaksimalkan penggunaan media yang berbasis komputer seperti powerpoint dan bahan ajar yang selama ini digunakan adalah buku teks dengan menggunakan media papan tulis, akibatnya, siswa tidak memahami materi dengan baik dan mempengaruhi hasil belajar dan nilai siswa. Kondisi siswa yang tidak terlalu siap dalam menerima pelajaran di kelas sering kali membuat mereka tidak mengerti dengan materi yang di sampaikan guru di dalam kelas. Penggunaan media menjadi kendala dalam proses pembelajaran berlangsung. Oleh karena itu, diperlukan sebuah media pembelajaran berbasis teknologi yang relevan dengan kebutuhan siswa yang mudah diakses dan dapat mendukung proses pembelajaran baik di dalam maupun di luar kgiatan mengajar di kelas. 
Saat ini Teknologi Informasi dan Komunikasi telah berkembang dengan sangat pesat termasuk teknologi smartphone. Smartphone memiliki sistem operasi dan salah satunya yang diminati saat ini adalah android [8]. Android merupakan sistem operasi yang berbasis open source. Sistem operasi android dengan berbagai macam pengembangan aplikasinya mampu menghasilkan media pembelajaran yang representatif. Dengan teknologi bebasis android pembelajaran tidak akan monoton dengan teks saja, tetapi bisa membuat unsur-unsur audio atau visual bahkan animasi untuk mempermudah siswa dalam memahami materi pembelajaran dan dapat memberikan hasil yang maksimal [9], [4], [10].

Adapun tujuan penelitian ini adalah untuk mengembangkan dan menghasilkan media pembelajaran matematika interaktif berbasis android pada materi dimensi tiga untuk siswa kelas XSMA.

\section{METODOLOGI PENELITIAN}

Jenis penelitian ini adalah Research and Development (R \& D). Penelitian pengembangan adalah metode penelitian yang digunakan untuk menghasilkan produk tertentu, dan menguji keefektifan produk tersebut [11], [12]. Pendapat lain mengatakab bahwa penelitian dan pengembangan merupakan penelitian yang mengembangkan produk-produk tertentu untuk mengetahui kebutuhan-kebutuhan tertentu dengan spesifikasi yang detail [13],[14]. Jadi penelitian pengembangkan merupakan metode untuk menghasilkan produk tertentu atau menyempurnakan produk yang telah ada serta menguji keefektifan produk tersebut.

Produk yang dihasilkan dalam penelitian pengembangan ini berupa media pembelajaran matematika interaktif pada materi dimensi tiga berbasis android untuk siswa kelas X SMA. Model pengembangan media pembelajaran yang digunakan dalam penelitian ini adalah Analisis (analysis), Perancangan (design), Pengembangan (development), Implementasi (implementation), Evaluasi (evaluation).

\section{HASIL DAN PEMBAHASAN}

\section{a. Hasil Uji Validitas}

Sebelum melakukan uji coba produk tersebut, peneliti melakukan validasi media kepada validator I dan validasi materi kepada guru mata pelajaran matematika di SMAN 1 Maronge yaitu: Validator II. Maka diperoleh hasil perhitungan penilaian dari para validator dapat dilihat pada Tabel 1 di bawah ini.
Tabel 1. Hasil Validasi

\begin{tabular}{|c|c|c|c|c|}
\hline No & Validator & Ahli & Skor & Kategori \\
\hline 1 & Validator 1 & Media & 32 & $\begin{array}{l}\text { Cukup } \\
\text { Valid }\end{array}$ \\
\hline 2 & Validator 2 & Materi & 40 & Valid \\
\hline \multicolumn{3}{|c|}{ a-rata } & 36 & Valid \\
\hline
\end{tabular}

Berdasarkan Tabel 1 hasil validasi skor rata-rata mencapai 36 yang berarti masuk dalam kategori "Valid".

\section{b. Hasil Uji Coba Kelompok Kecil}

Uji coba kelompok kecil tersebut dilakukan pada tanggal 11 April kepada 5 siswa di kelas X IPA di SMAN 1 Maronge untuk mengetahui keefektifan dan kepraktisan produk yang dikembangkan.

a) Uji Efektifitas

Uji efektifitas dilakukan menggunakan tes siswa atau evaluasi dapat dilihat pada Tabel 2 di bawah ini.

Tabel 2. Hasil Tes Siswa Uji Coba Kelompok Kecil

\begin{tabular}{|c|c|c|}
\hline No & Nama & Nilai \\
\hline 1 & Responden 1 & 100 \\
\hline 2 & Responden 2 & 100 \\
\hline 3 & Responden 3 & 100 \\
\hline 4 & Responden 4 & 100 \\
\hline 5 & Responden 5 & 100 \\
\hline & Jumlah & 500 \\
\hline & Rata-rata & 100 \\
\hline \multicolumn{2}{|r|}{ Kategori } & $\begin{array}{l}\text { Sangat } \\
\text { Efektif }\end{array}$ \\
\hline
\end{tabular}

Adapun hasil efektifitas media pembelajaran dapat dilihat pada Tabel 2 dengan ketuntasan belajar mencapai $100 \%$, maka masuk dalam kategori "Sangat Efektif".

b) Uji Kepraktisan

Uji kepraktisan dilakukan menggunakan angket respon siswa dapat dilihat pada Tabel 3 di bawah ini.

Tabel 3 Hasil Angket Respon Siswa Uji Coba Kelompok Kecil

\begin{tabular}{|c|l|c|}
\hline No & Nama & Skor \\
\hline 1 & Responden 1 & 57 \\
\hline 2 & Responden 2 & 58 \\
\hline 3 & Responden 3 & 59 \\
\hline 4 & Responden 4 & 55 \\
\hline 5 & Responden 5 & 56 \\
\hline \multicolumn{2}{|c|}{ Jumlah } & $\mathbf{2 8 5}$ \\
\hline & Rata-rata & $\mathbf{5 7}$ \\
\hline
\end{tabular}




\begin{tabular}{|c|c|}
\hline Kategori & $\begin{array}{l}\text { Sangat } \\
\text { Praktis }\end{array}$ \\
\hline
\end{tabular}

Adapun hasil kepraktisan media pembelajaran dapat dilihat pada Tabel 3 dengan ketuntasan belajar mencapai 57 yang artinya masuk "Sangat Praktis".

\section{c. Hasil Uji Coba Kelompok Besar}

Uji coba kelompok besar tersebut dilakukan di dua kelas untuk membandingkan hasil keefektifan dan kepraktisan media yang dikembangkan.

\section{Kelas X IPA}

Uji coba kelompok besar yang dilakukan pada tanggal 11 April di kelas X IPA kepada 25 siswa untuk mengetahui keefektifan dan kepraktisan produk yang dikembangkan.

\section{a) Uji Efektifitas}

Uji efektifitas dilakukan menggunakan tes siswa atau evaluasi. Kemudian untuk penentuan kriteria ketuntasan belajar siswa dapat dilihat pada Gambar 1 di bawah ini.

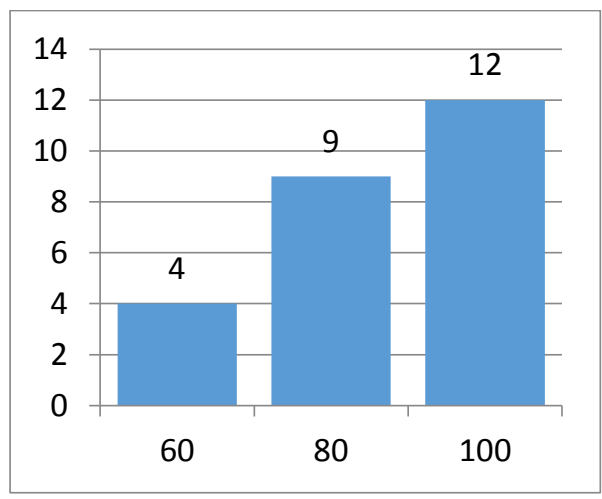

Gambar 1. Hasil Uji Efektivitas

Adapun hasil efektifitas media pembelajaran dapat dilihat pada Gambar 1 di atas dengan ketuntasan belajar mencapai 84\%. Maka masuk dalam kategori "Sangat Efektif".

\section{b) Uji Kepraktisan}

Uji kepraktisan dilakukan menggunakan angket respon siswa. Kemudian untuk penentuan kepraktisan produk dapat dilihat pada Gambar 2 di bawah ini.

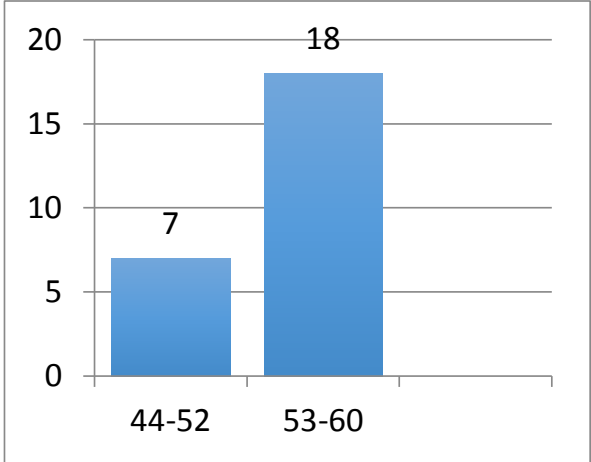

Gambar 2. Hasil Uji Kepraktisan
Adapun hasil kepraktisan media pembelajaran dapat dilihat pada Gambar 2 dengan ketuntasan belajar mencapai 53,52. Maka masuk dalam kategori "Sangat Praktis".

\section{Kelas X IPS}

Uji coba kelompok besar yang dilakukan pada tanggal 16 April di kelas X IPS kepada 25 siswa untuk mengetahui keefektifan dan kepraktisan produk yang dikembangkan.

a) Uji Efektifitas

Uji efektifitas dilakukan menggunakan tes siswa atau evaluasi. Kemudian untuk penentuan kriteria ketuntasan belajar siswa dapat dilihat pada Gambar 3 di bawah ini.

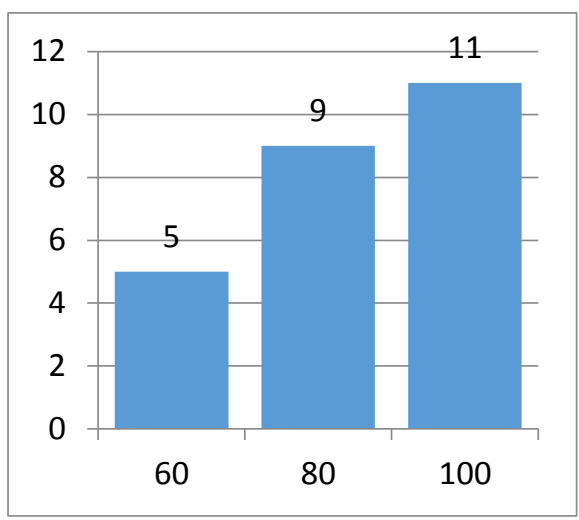

Gambar 3. Hasil Uji Efektivitas

Adapun hasil efektifitas media pembelajaran dapat dilihat pada Gambar 4.5 dengan ketuntasan belajar mencapai $80 \%$. Maka masuk dalam kategori "Efektif".

b) Uji Kepraktisan

Uji kepraktisan dilakukan menggunakan angket respon siswa. Kemudian untuk penentuan kepraktisan produk dapat dilihat pada Gambar 4 di bawah ini.

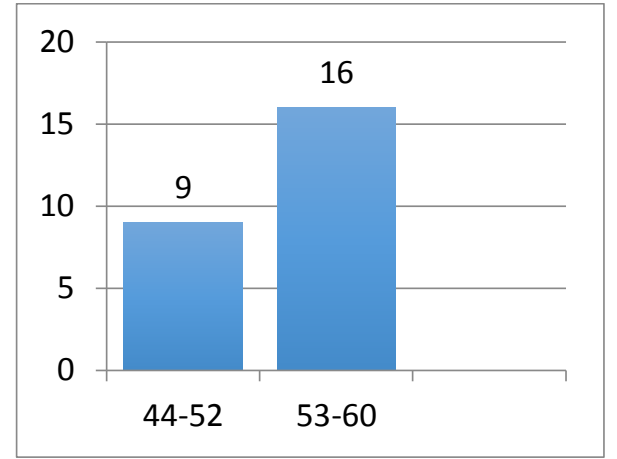

Gambar 4. Hasil Uji Kepraktisan

Adapun hasil kepraktisan media pembelajaran dapat dilihat pada Gambar 4 dengan ketuntasan belajar mencapai 55,45. Maka masuk dalam kategori "Sangat Praktis". 


\section{KESIMPULAN}

Penelitian dan pengembangan ini menghasilkan produk media pembelajaran matematika interaktif berbasis android yang dikemas dalam bentuk APK dan dapat dioperasikan di smartphone. Pengembangan media pembelajaran ini dikembangkan dengan model pengembangan yang mangacu pada rancangan penelitian dan pengembangan ADDIE. Model pengembangan ini menggunakan 5 tahap yang terdiri (1) analysis; (2) design; (3) development; (4) implementation; dan (5) evaluation. Materi yang dibahas pada produk pengembangan media pembelajaran berbasis multimedia interaktif ini adalah dimensi tiga untuk siswa kelas X SMA. Media pembelajaran ini terdiri dari beberapa menu yang bisa dioperasikan dan membantu siswa dalam belajar. Terdapat fasilitas simulasi dan tes sebagai penunjang konsep dan dikerjakan secara individu sebagai pengukur keberhasilan dari standar kompetensi yang diharapkan.

Berdasarkan analisis data dan pembahasan maka dapat disimpulkan beberapa hal sebagai berikut: a) Hasil akhir produk yang dikembangkan berupa aplikasi media pembelajaran interaktif berbasis android pada materi dimensi tiga. b) Aplikasi media pembelajaran dimensi tiga berdasarkan uji validasi memperoleh rata-rata mencapai 36 yang artinya sudah masuk dalam kategori "Valid". c) Aplikasi media pembelajaran dimensi tiga berdasarkan uji coba kelompok kecil memperoleh ketuntasan belajar mencapai $100 \%$ dan skor rata-rata mencapai 57 yang artinya sudah masuk dalam kategori "Sangat Efektif" dan "Sangat Praktis". d) Media pembelajaran dimensi tiga berdasarkan uji coba kelompok besar memperoleh ketuntasan belajar mencapai $82 \%$ dan skor rata-rata mencapai 54,445 yang artinya sudah masuk dalam kategori "Efektif" dan "Sangat Praktis".

Saran pemanfaatan produk pengembangan media pembelajaran matematika interaktif berbasis android adalah a) Aplikasi media pembelajaran dimensi tiga ini sudah valid, efektif, dan praktis, maka bisa digunakan oleh guru untuk media pembelajaran di kelas. b) Aplikasi media pembelajaran dimensi tiga bisa juga digunkan untuk sumber belajar mandiri siswa dimana saja. c)Aplikasi media pembelajaran dimensi tiga ini hanya terbatas pada satu kompetensi dasar yaitu kedudukan konsep titik, garis dan bidang dalam ruang, maka disarankan kepada peneliti selanjutnya untuk mengembangkan pada materi yang lain.

\section{DAFTAR PUSTAKA}

[1] Rudi Ahmad Suryadi, "Refomulasi Epistemologi Islami Mengenai Tujuan Pendidikan," J. Pendidik. Agama Islam Ta'lim, vol. 13, no. 2, pp. 137-156, 2015.

[2] J. Lilawati, "Analisis Pemanfaatan Sumber Belajar dalam Proses Pembelajaran," in Prosiding Seminar Nasional Tahunan Fakultas Ilmu Sosial Universitas Negeri Medan, 2017, pp. 106-109.

[3] T. Agung Saputro, K. Kriswandani, and N. Ratu, "Pengembangan Media Pembelajaran Mengunakan Aplikasi Construct 2 Pada Materi Aljabar Kelas VII," JTAM |J. Teor. dan Apl. Mat., vol. 2, no. 1, p. 1, 2018.

[4] B. O. Aini, K. C. Ayu, and S. Siswati, "Pengembangan Game Puzzle Sebagai Edugame Berbasis Android Untuk Meningkatkan Kemampuan Berpikir Matematika Siswa SD," JTAM $\mid$ J. Teor. dan Apl. Mat., vol. 3, no. 1, p. 74, 2019.

[5] S. Sirajuddin, "Pengembangan Perangkat Pembelajaran Matematika Dengan Kombinasi Pendekatan Matematika Realistik Dan Scientific Pada Siswa Kelas VII SMP," JTAM |J. Teor. dan Apl. Mat., vol. 1, no. 1, p. 60, 2017.

[6] A. Chaerunisa, "Pengembangan E-Module Berbasis Multimedia Interaktif Dengan Pendekatan Contextual Teaching And Learning (CTL) Pada Pokok Bahasan Statistika Untuk Siswa Kelas X SMA/MA," JPM J. Pendidik. Mat., vol. 3, no. 1, p. 16, 2019.

[7] A. Komalasari and D. Darmasih, "Peningkatan Hasil Belajar Matematika Melalui Strategi Pembelajaran KreatifProduktif Pada Materi Operasi Aljabar," JTAM $\mid$ J. Teor. dan Apl. Mat., vol. 3, no. 1, p. 46, 2019.

[8] R. Y. Arindiono and N. Ramadhani, "Perancangan Media Pembelajaran Interaktif Matematika Untuk Siswa Kelas 5 SD,” J. Sains dan Seni Pomits, vol. 2, no. 1, pp. 28-32, 2013.

[9] S. Sanusi, E. Suprapto, and D. Apriandi, "Pengembangan Multimedia Interaktif Sebagai Media Pembelajaran pada Pokok Bahasan Dimensi Tiga di Sekolah 
Menengah Atas (SMA)," JIPM (Jurnal Ilm. Pendidik. Mat., vol. 3, no. 2, 2015.

[10] H. Ratu, P. Negara, K. Riska, A. Kurniawati, and V. Mandailina, "MENINGKATKAN MINAT BELAJAR SISWA MELALUI PEMANFAATAN MEDIA," vol. 2, 2019.

[11] Sugiyono, "Metode Penelitian Pendidikan Pendekatan Kuantitaif, Kualitatif, dan R\&D," Metode Penelitian Pendidikan Pendekatan Kuantitaif, Kualitatif, dan $R \& D$. pp. 283-393, 2013.

[12] V. Mandalina, S. Syaharuddin, M. Firdaus, A. Abdillah, D. Pramita, and H. R. P. Negara, "Math Mobile Learning App As An Interactive Multimedia Learning Mathematics," Int. J. Sci. Technol. Res., vol. 8, no. 10, 2019.

[13] Herlinda dkk, "Analisis dan Pengumpulan Data Kualitatif," in Metodologi Penelitian, 2010, pp. 61-103.

[14] R. A. Kurniawati et al., "Worksheet Persamaan Differensial untuk Meningkatkan Kemandirian Belajar Mahasiswa," vol. 3, no. 2, pp. 149-155, 2019. 